Original Article

\title{
Pengetahuan dan Sikap Guru Tentang Mitigasi Bencana Gempa Bumi dan Tsunami Di Daerah Rawan Tsunami Kota Palu
}

\section{Teachers ' Knowledge and Attitudes About The Mitigation of Earthquake and Tsunami Prone Areas of Tsunami In Palu City Puskesmas}

\author{
Christine*, Fellysca V. M. Politon, Ellen \\ Poltekkes Kemenkes Palu \\ (*christinekromoprawiro@gmail.com)
}

\begin{abstract}
ABSTRAK
Penelitian ini bertujuan untuk mengetahui pengetahuan dan sikap guru tentang mitigasi bencana gempa bumi dan tsunami di SDN 01 dan SDN 02 Talise Kota Palu. Penelitian ini merupakan penelitian deskriptif, populasi dan sampel adalah guru di SDN 01 dan SDN 02 Talise Kota Palu sejumlah 43 orang ( 23 orang di SDN 01 Talise dan 20 orang di SDN 02 Talise Kota Palu). Hasil penelitian ini menunjukkan bahwa pengetahuan responden tentang mitigasi bencana gempa bumi dan tsunami, yang berpengetahuan baik sebanyak 22 responden $(51,2 \%)$, yang cukup sebanyak 20 responden $(46,5 \%)$, dan yang kurang sebanyak 1 responden $(2,3 \%)$. Sikap responden tentang mitigasi bencana gempa bumi dan tsunami, lebih banyak yang bersikap positif sebanyak 29 responden $(67,4 \%)$ dari pada yang bersikap negatif sebanyak 14 responden $(32,6 \%)$. Saran bagi SDN 01 dan SDN 02 Talise Kota Palu, perlu adanya buku panduan khusus mengenai materi kebencanaan dan mitigasinya baik bagi guru maupun peserta didik.
\end{abstract}

Kata kunci: Pengetahuan, sikap, gempa bumi, tsunami, mitigasi, guru

\section{ABSTRACT}

This research aims to determine the knowledge and attitudes of teachers on the mitigation of earthquake and tsunami disasters at SDN 01 and SDN 02 Talise Kota Palu. This research is a descriptive study, population and samples are teachers at SDN 01 and SDN 02 Talise Kota Palu A number of 43 people (23 people at SDN 01 Talise and 20 people at SDN 02 Talise Kota Palu). The results showed that the respondents ' knowledge of the earthquake and tsunami disaster mitigation, which was well-rounded by 22 respondents $(51.2 \%)$, of which enough 20 respondents (46.5\%), and the less than 1 respondent $(2.3 \%)$. The respondents ' stance on the mitigation of earthquake and tsunami disasters, more positive 29 respondents (67.4\%) Negative of 14 respondents (32.6\%). Advice for SDN 01 and SDN 02 Talise Kota Palu, there is a need for particular handbook on disaster materials and their mitigations for both teachers and learners.

Key words: Knowledge, attitude, earthquake, tsunami, mitigation, teacher

\section{https://doi.org/10.33860/jik.v15i1.376}




\section{PENDAHULUAN}

Indonesia merupakan salah satu negara dengan tingkat aktivitas gempa bumi tinggi, hal tersebut dikarenakan Indonesia terletak pada jalur pertemuan 3 lempeng tektonik dunia yakni: lempeng Indo-Australia, lempeng Pasifik dan lempeng Eurasia. Lempeng Eurasia dan Indo-Australia bertumbukan di lepas pantai barat pulau Sumatera, di selatan pulau Jawa, di selatan kepulauan Nusa Tenggara, dan berbelok ke arah utara ke perairan Maluku sebelah selatan. Sedangkan lempeng Australia dan Pasifik bertumbukan di sekitar Pulau Papua. Pertemuan antar lempeng ini menyebabkan sering terjadinya gempa bumi karena tumbukan atau pergeseran lempeng. Oleh karena itu, Indonesia merupakan daerah yang secara tektonik rawan gempa bumi. ${ }^{1}$

Bencana gempa bumi, tsunami dan likuifaksi pada hari Jumat 28 September 2018 yang melanda 4 daerah di Sulawesi Tengah yaitu Kota Palu, Kabupaten Donggala, Sigi dan Parigi Moutong. Dampak bencana hingga Minggu (21/10/2018) pukul 13.00 WIB, tercatat 2.256 orang meninggal dunia. Sebarannya di Kota Palu 1.703 orang meninggal dunia, Donggala 171 orang, Sigi 366 orang, Parigi Moutong 15 orang dan Pasangkayu 1 orang. Semua korban sudah dimakamkan. Sebanyak 1.309 orang hilang, 4.612 orang luka-luka dan 223.751 orang mengungsi di 122 titik. $^{2}$

Salah satu sekolah yang terkena dampak gempa bumi dan tsunami adalah SDN 01 dan SDN 02 Talise Kelurahan Talise Kecamatan Mantikulore Kota Palu, dengan jumlah guru SDN 01 sebanyak 23 orang dan jumlah guru SDN 02 sebanyak 20 orang. Sekolah ini berlokasi tidak jauh dari pantai talise, lokasi dimana terjadi bencana tsunami. Untuk mengurangi konsekuensi bencana dan marabahaya seperti yang terjadi di Kota Palu dan Sekitarnya guru perlu di bekali pengetahuan tentang mitigasi bencana gempa bumi dan tsunami.

Mitigasi adalah tindakan untuk mengurangi konsekuensi bencana dan marabahaya. Mitigasi merupakan upaya mengurangi kerawanan dan kerapuhan yang ditemukan dalam komunitas, baik sebelum maupun sesudah terjadi bencana. Misalnya, Sebelum terjadi gempa bumi struktur bangunan dibuat menjadi tahan-gempa. Semua itu merupakan upaya mitigasi sebelum terjadi bencana. Bila dilakukan setelah bencana terjadi, mitigasi merupakan bagian integral daripada fase rekonstruksi atau rehabilitasi. ${ }^{3}$

Guru umumnya merujuk pendidik profesional dengan tugas utama mendidik, mengajar, membimbing, mengarahkan, melatih, menilai, dan mengevaluasi peserta didik. Guru memiliki peran penting terhadap siswa karena sebagai penyampai ilmu. ${ }^{4} \mathrm{Hal}$ inilah yang melatarbelakangi penelitian ini mengenai pemahaman guru tentang Mitigasi Bencana Gempa Bumi dan Tsunami di SDN 01 dan SDN 02 Talise Kota Palu, dengan judul Pengetahuan dan Sikap Guru tentang Mitigasi Bencana Gempa Bumi dan Tsunami di SDN 01 dan SDN 02 Talise Kota Palu.

\section{METODE PENELITIAN}

Jenis penelitian ini adalah deskriptif yaitu suatu metode penelitian yang dilakukan dengan tujuan utama untuk mengukur gambaran atau deskripsi tentang suatu keadaan secara objektif (Notoamodjo,2005). Dalam penelitian ini yang akan dideskripsikan adalah pengetahuan dan sikap guru tentang mitigasi bencana gempa bumi dan tsunami di SDN 01 dan SDN 02 Talise Kota Palu. Waktu penelitian ini dilaksanakan pada Bulan Mei 2019 di SDN 01 dan SDN 02 Talise Kota Palu. Populasi dalam penelitian ini adalah guru di SDN 01 dan SDN 02 Talise Kota Palu yang berjumlah 43 orang. Selanjutnya data dianalisis dan menyajikan dalam bentuk tabel dan grafik.

\section{HASIL}

Tabel 1 menununjukkan bahwa berrdasarkan jenis kelamin, mayoritas guru di SDN 01 dan SDN 02 Talise Kota Palu adalah perempuan. Berdasarkan umur, sebagian guru berada pada kelompok umur 41-50 tahun. Sedangkan berdasarkan tingkat pendidikan, mayoritas guru berpendidikan sarjana (S1).

Gambar 1 menunjukkan distribusi pengetahuan guru tentang mitigasi bencana gempa bumi dan tsunami di SDN 01 dan SDN 02 Talise Kota Palu, menunjukan mayoritas guru memiliki pengetahuan yang baik dan cukup. Namun, masih ada guru yang pengetahuannya kurang tentang mitigasi bencana gempa bumi dan tsunami.

Gambar 2 menunjukkan distribusi sikap guru tentang mitigasi bencana gempa bumi dan tsunami di SDN 01 dan SDN 02 Talise Kota Palu, sebagian besar guru memiliki sikap positif. Akan tetapi masih ada juga guru yang 
memiliki sikap negatif tentang mitigasi bencana.

Tabel 1. Distribusi Frekuensi Berdasarkan Jenis Kelamin, Umur dan Tingkat Pendidikan

\begin{tabular}{lcc}
\hline \multicolumn{1}{c}{ Variabel } & n & \% \\
\hline Jenis kelamin & & \\
a. Laki-laki & 4 & 9,3 \\
b. Perempuan & 39 & 90,7 \\
Umur & & \\
a. 20 - 30 & 14 & 4,7 \\
b. 31 - 40 & 6 & 23,3 \\
c. 41 - 50 & 19 & 44,2 \\
d. >50 & 12 & 27,9 \\
Tingkat pendidikan & & \\
a. D2 & 5 & 11,6 \\
b. S1 & 34 & 79,1 \\
c. S2 & 4 & 9,3 \\
\hline
\end{tabular}

\section{PEMBAHASAN}

Pengetahuan atau kognitif merupakan domain yang sangat penting dalam bentuk tindakan seseorang (over behavior) karena dari pengalaman dan penelitian, terbukti bahwa perilaku yang didasari pengetahuan akan lebih langgeng dari pada perilaku yang tidak didasari oleh pengetahuan. ${ }^{5}$ Pengetahuan terkait dengan persiapan menghadapi bencana pada kelompok rentan bencana menjadi fokus utama. Berbagai pengalaman menunjukkan bahwa kesiapan menghadapi bencana ini seringkali terabaikan pada masyarakat yang belum memiliki pengalaman langsung dengan bencana. ${ }^{6}$ Pengetahuan merupakan faktor utama kunci kesiapsiagaan. Pengalaman bencana gempa bumi dan tsunami di Aceh, Nias dan Yogyakarta serta berbagai bencana yang terjadi diberbagai daerah lainnya memberikan pelajaran yang sangat berarti akan pentingnya pengetahuan mengenai bencana alam. Pengetahuan yang dimiliki biasanya dapat memengaruhi sikap dan kepedulian masyarakat untuk siap dan siaga dalam menghadapi bencana, terutama bagi mereka yang bertempat tinggal di daerah pesisir yang rentan terhadap bencana alam. ${ }^{7}$

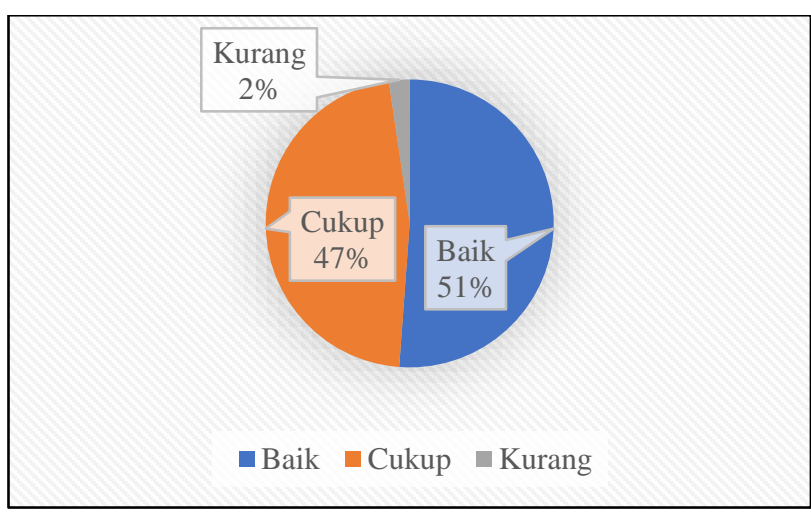

Gambar 1. Distribusi Pengetahuan Guru tentang Mitigasi Bencana

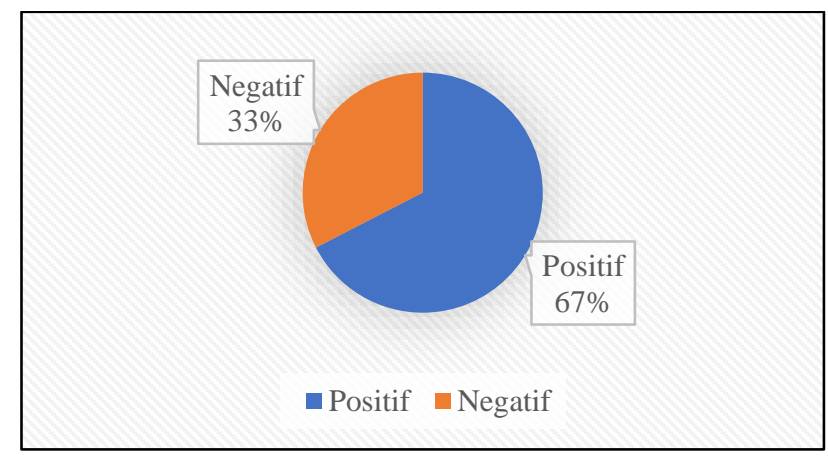

Gambar 2. Distribusi Sikap Guru tentang Mitigasi Bencana

Berdasarkan hasil penelitian distribusi responden menurut pengetahuan tentang mitigasi bencana gempa bumi dan tsunami di SDN 01 dan SDN 02 Talise Kota Palu, menunjukan bahwa responden yang memiliki pengetahuan yang baik tentang mitigasi bencana gempa bumi dan tsunami sebanyak 22 responden $(51,2 \%)$ sedangkan yang memiliki pengetahuan cukup sebanyak 20 responden $(46,5 \%)$ dan memiliki pengetahuan kurang sebanyak 1 responden $(2,3 \%)$. Pengetahuan yang baik tentang mitigasi dapat disebabkan guru telah dapat memperoleh informasi tentang mitigasi bencana gempa bumi dan tsunami melalui penyuluhan dari BPPT (Badan Pengkajian dan Penerapan Teknologi) pusat, media elektronik atau media cetak. Faktor lain yang mendukung pengetahuan yang baik adalah tingkat pendidikan responden yang sudah tergolong strata 1 sebanyak 38 orang. Dengan demikian guru sudah lebih memahami tentang pentingnya mitigasi bencana gempa bumi dan tsunami. Pengetahuan mengenai mitigasi menghadapi bencana adalah kemampuan yang harus dimiliki oleh setiap individu sebagai wujud dari kesiapsiagaan dalam menghadapi bencana gempa bumi. Individu, atau 
masyarakat yang memiliki pengetahuan yang lebih baik terkait dengan bencana yang terjadi cenderung memiliki kesiapsiagaan yang lebih baik dibandingkan individu, atau masyarakat yang minim memiliki pengetahuan. Pemahaman dan pengetahuan tentang bencana adalah modal dasar dalam konsep mitigasi dan kesiapsiagaan terhadap bencana. ${ }^{8}$

Bashori dalam penelitiannya tentang peran guru terhadap kesiapsiagaan sekolah dalam menghadapi bencana banjir di Kelurahan Jebres Kota Surakarta, menyatakan bahwa pengetahuan dasar bencana merupakan indikator yang sangat mendasar dalam kemampuan guru saat menghadapi bencana, karena guru tidak mungkin mampu menyikapi dan merespon potensi bencana yang ada dilingkungan sekolah tanpa memiliki dasar pengetahuan yang baik. Hasil rata-rata nilai dari pengetahuan mitigasi bencana sebesar $75 \%$ sehingga dapat dikategorikan pengetahuan mitigasi bencana guru baik. ${ }^{9}$ Beberapa penelitian lain juga menunjukkan hasil serupa. Penelitian yang dilakukan oleh Wulandari menyatakan tingkat pengetahuan guru dalam mitigasi bencana gempa bumi di SMP Negeri 2 Gantiwarno termasuk dalam kategori tinggi dengan presentase $79,64 \% .{ }^{10}$ Penelitian lain oleh Aprilia dalam penelitiannya tentang pengetahuan guru dalam mitigasi bencana gempa bumi di SMK Muhammadiyah 02 Wedi yang berjumlah 23 guru menunjukan bahwa tingkat pengetahuan guru dalam mitigasi bencana gempa bumi yang terdiri dari 7 parameter masuk dalam kategori cukup. ${ }^{11}$

Strategi umum dalam mewujudkan visi dan misi ketangguhan bangsa menghadapi bencana meliputi upaya menjauhkan masyarakat dari bencana; menjauhkan bencana dari masyarakat; hidup harmoni dengan risiko bencana; dan menumbuhkembangkan dan mendorong kearifan lokal masyarakat dalam penanggulangan bencana. Strategi umum tersebut diterapkan dalam penyelenggaraan penanggulangan bencana yang meliputi kegiatan tahap prabencana, saat tanggap darurat, maupun pascabencana, yang dituangkan dalam strategi khusus yang meliputi mengurangi risiko bencana (reduce the risk), menyelamatkan sebanyak mungkin nyawa (save more lives), membangun kembali lebih baik dan lebih aman (built back better and safer). ${ }^{12}$

Pengetahuan kebencanaan akan dibutuhkan masyarakat yang tinggal di daerah rawan bencana, karena berbagai informasi mengenai jenis bencana yang mungkin mengancam mereka, gejala - gejala bencana perkiraan daerah jangkauan bencana, prosedur penyelamatan diri, tempat yang disarankan untuk mengungsi, dan informasi lain yang mungkin dibutuhkan masyarakat pada sebelum, saat dan pasca bencana itu terjadi dapat meminimalkan risiko bencana Semakin sering seseorang terpapar bencana, semakin menambah pengetahuan dan sikap terhadap bencana yang dimilikinya. Hasil pilot survei pengetahuan (Knowledge), sikap (Attitude) dan perilaku (Practice) BNPB di Kota Padang menjelaskan bahwa dari 250 rumah tangga terpilih dari 10 kelurahan terpilih, hampir semua $(99,2 \%)$ responden yang pernah mengalami kejadian bencana gempa bumi. Seringnya mengalami kejadian gempa bumi menjadikan tingginya pengetahuan masyarakat dalam menghadapi bencana gempa bumi. Ini dapat diartikan bahwa pengalaman mengalami bencana berpengaruh pada tingginya pengetahuan dan sikap masyarakat dalam menghadapi risiko bencana ${ }^{13}$. Selain itu penelitian Indraswari menyebutkan, pengalaman atau kejadian bencana yang pernah dialami oleh individu dapat menstimulus individu untuk memahami proses menghadapi bencana, sehingga hal ini dapat berpengaruh terhadap proses kesiapsisagaan bencana terutama pada pengetahuan dan sikap menghadapi risiko bencana. ${ }^{14}$

Sekolah memiliki peran mendasar dalam memperluas pemahaman tentang bahaya dan risiko alam serta dalam membangun kesadaran di masyarakat. Kerja sama dengan para guru, kami bertujuan mengembangkan kurikulum yang sesuai dengan usia untuk meningkatkan pengetahuan siswa tentang gempa bumi, keamanan seismik, dan pengurangan risiko seismik $^{15}$. Pengetahuan yang dimiliki oleh guru biasanya dapat memengaruhi sikap dan kepedulian para siswa untuk siap dan siaga dalam menghadapi bencana, terutama bagi mereka yang bertempat tinggal di daerah pesisir yang rentan terhadap bencana alam. ${ }^{16}$

Guru yang memiliki sikap positif tentang mitigasi bencana gempa bumi dan tsunami sebanyak 29 responden $(67,4 \%)$. Menurut peneliti, sikap baik dari responden dapat berawal dari pengetahuan yang baik, sehingga memberikan dorongan yang menimbulkan responden yang baik tentang mitigasi bencana gempa bumi dan tsunami. 
Responden yang memiliki sikap negatif sebanyak 14 responden (32,6\%). Menurut peneliti hal ini disebabkan karena kurangnya perhatian tentang pentingnya mitigasi bencana gempa bumi dan tsunami serta kurang mengetahui keuntungan dan kerugian apabila tidak mengetahui mitigasi bencana gempa bumi dan tsunami yang menyebabkan besarnya konsekuensi bencana dan marabahaya.

Sikap merupakan perwujudan dari pengetahuan yang diimplementasikan melalui sebuah tindakan dan keterampilan untuk mempertahankan diri dalam menghadapi bencana. Ada beberapa masalah yang perlu diperhatikan, seperti terbatasnya sumber daya manusia yang mampu menerapkan mitigasi tersebut dan kemampuan guru tentang mitigasi bencana yang terbatas. Penerapan mitigasi ini belum dapat menjadi dasar penerapan yang berkelanjutan. Di Indonesia ini memang rawan sekali terjadi bencana alam seperti yang juga terjadi di Aceh. Penerapan mitigasi ini belum dapat menjadi dasar penerapan yang

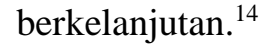

Kegiatan kesiapsiagaan kebencanaan merupakan landasan pertama dalam menurangi resiko korban bencana dan baik jika dilakukan sejak dini terutama ketika SD karena siswa SD berada pada masa operasional konkrit. Dengan dilakukannya pelatihan itu sudah membuktikan bahwa penerapan mitigasi tersebut dapat meningkatkan kesiapsiagaan siswa. Dalam penelitian yang dilakukan itu ternyata sudah ada banyak guru yang mempunyai pengetahuan cukup tentang mitigasi bencana walaupun sebelumnya ada beberapa faktor penghambat yang mengatakan bahwa ada guru yang belum mampu memahami penerapan mitigasi bencana tersebut. $^{14}$

Kendala dalam melakukan pengurangan resiko bencana di sekolah adalah pengetahuan dan kemampuan guru, panduan, dan gedung sekolah. Walaupun demikian, dinyatakan juga bahwa masalah mitigasi gempa bumi hendaknya masuk dalam kurikulum pendidikan dari jenjang SD sampai dengan SMA. Pada saat ini, baik prasarana maupun sarana yang tersedia di sekolah masih banyak yang belum memenuhi syarat sebagai prasarana dan sarana yang memberikan keamanan bagi siswa apabila terjadi gempa bumi. Misalnya, tidak semua sekolah memiliki halaman kosong yang cukup sebagai tempat evakuasi, bangunan gedung yang sederhana dan kurang menjamin keselamatan penghuninya, dan bangku- bangku sekolah yang belum disiapkan sebagai tempat berlindung. Di masa yang akan datang, pembangunan prasarana dan sarana pendidikan di sekolah hendaknya mempertimbangkan fungsi bangunan sebagai tempat belajar dan sekaligus sebagai tempat berlindung dari bahaya gempa bumi. Gedung-gedung sekolah hendaknya dibangun sesuai dengan standar ketahanan gempa, halaman sekolah dipersiapkan sebagai tempat evakuasi sementara, dan bangku- bangku dibuat sebagai tempat berlingsung di dalam kelas. ${ }^{17}$.

\section{KESIMPULAN DAN SARAN}

Berdasarkan hasil penelitian di SDN 01 dan SDN 02 Talise Kota Palu dapat diambil kesimpulan mayoritas guru memiliki pengetahuan yang baik dan cukup, namun masih ada guru yang pengetahuannya kurang tentang mitigasi bencana gempa bumi dan tsunami. Sebagian besar guru memiliki sikap positif. Akan tetapi masih ada juga guru yang memiliki sikap negatif tentang mitigasi bencana. Saran untuk sekolah, perlu adanya buku panduan khusus mengenai mitigasi bencana baik bagi guru maupun peserta didik. Selain itu, materi tentang mitigasi bencana sebaiknya dimasukkan dalam kurikulum, seperti muatan lokal.

\section{DAFTAR PUSTAKA}

1. Indonesia Tsunami Early Warning System - InaTEWS :. [Internet]. [cited 2021 May 26]. Available from: http://inatews2.bmkg.go.id/new/tentang _eq.php

2. Badan Nasional Penanggulangan Bencana. Info Bencana: Informasi Kebencanaan Bulanan Teraktual [Internet]. 2018 [cited 2021 May 26]. Available from: www.bnpb.go.id

3. Purwana R. Manajemen Kedaruratan Kesehatan Lingkungan dalam Kejadian Bencana. Jakarta: Rajawali Press; 2019.

4. Undang-undang Republik Indonesia Nomor 14 Tahun 2005 tentang Guru dan Dosen.

5. Notoatmodjo S. Ilmu Perilaku Kesehatan. Jakarta: Rineka Cipta; 2010.

6. Setyawati H. Hubungan Antara Pengetahuan Dengan Kesiapsiagaan Bencana Gempa Bumi pada Siswa Kelas XI IPS SMAN 1 Cawas Kabupaten Klaten. Universitas Muhammadiyah Surakarta; 2014.

7. Hidayat D. Kesiapsiagaan Masyarakat: 
Paradigma Baru Pengelolaan Bencana Alam (Community Preparedness: New Paradigm in Natural Disaster Management). J Kependud Indones [Internet]. 2008;3(1):69-84. Available from:

http://ejurnal.kependudukan.lipi.go.id/i ndex.php/jki/article/view/164

8. Supartini E, Kumalasari N, Andry D, Susilastuti, Fitrianasari I, Tarigan J, et al. Membangun

Kesadaran,Kewaspadaan, dan Kesiapsiagaan dalam Menghadapi Bencana. Vol. 1, Buku Pedoman Latihan Kesiapsiagaan Bencana. 2017. $145 \mathrm{p}$.

9. Bashori I. Peran Guru Terhadap Kesiapsiagaan Sekolah Dalam Menghadapi Bencana Banjir di Kelurahan Jebres Kota Surakarta. Universitas Muhammadiyah Surakarta; 2013.

10. Wulandari A. Tingkat Pengetahuan Guru dalam Mitigasi Bencana Gempa Bumi di SMP Negeri 02 Gantiwarno Kabupaten Klaten. Universitas Muhammadiyah Surakarta; 2014.

11. Aprilia DM. Tingkat Pengetahuan Guru dalam Mitigasi Bencana Gempa Bumi di SMK Muhammadiyah 02 Wedi Kabupaten Klaten. Universitas Muhammadiyah Surakarta; 2014.

12. Badan Nasional Penanggulangan Bencana. Rencana Nasional Penanggulangan Bencana 2015-2019. Badan Nasional Penanggulangan Bencana; 2014.

13. Sularno S, Nurjazuli N, Raharjo $M$. Faktor-Faktor Yang Berhubungan Dengan Kejadian Filariasis Di Kecamatan Buaran Kabupaten Pekalongan. J Kesehat Lingkung Indones [Internet]. 2017 Mar 14 [cited 2019 Sep 27];16(1):22. Available from: http://ejournal.undip.ac.id/index.php/jkl i/article/view/12957

14. Indraswari D. Analisis Tingkat Pengetahuan Masyarakat Tentang Bencana Gempa Bumi dan Erupsi Gunung Berapi (Studi Kasus Kecamatan Prambanan Kabupaten Klaten). J Geogr. 2018;15(2).

15. Awareness and understanding of earthquake hazards at school NASA/ADS [Internet]. [cited 2021 May
27]. Available from: https://ui.adsabs.harvard.edu/abs/2014E GUGA..1615920S/abstract

16. Mohadjer S, Bendick R, Halvorson SJ, Saydullaev U, Hojiboev O, Stickler C, et al. Earthquake Emergency Education in Dushanbe, Tajikistan. J Geosci Educ. 2010;58(2):85-94.

17. Subagia IW, Wiratma I, Sudita IK. Pelatihan Mitigasi Bencana Alam Gempa Bumi Pada Siswa Sekolah Dasar Negeri 1 Pengastulan Kecamatan Seririt Kabupaten Buleleng Bali. J Pendidik Indones. 2015;4(1):585-98. 